\title{
Brazilein in Combination with Cisplatin Inhibit Proliferation and Migration on Highly Metastatic Cancer Cells, 4T1
}

\author{
Sri Handayani ${ }^{2,3}$, Ratna Asmah Susidarti ${ }^{1,2}$, Zalinar Udin ${ }^{3}$, Edy Meiyanto ${ }^{1,2}$, \\ Riris Istighfari Jenie ${ }^{1,2, *}$
}

\author{
${ }^{1}$ Faculty of Pharmacy, Universitas Gadjah Mada, Indonesia, 55281 \\ ${ }^{2}$ Cancer Chemoprevention Research Center, Faculty of Pharmacy, Universitas \\ Gadjah Mada, Indonesia, 55281 \\ ${ }^{3}$ Research Center for Chemistry, Indonesian Institute of Sciences (LIPI), Indonesia
}

\begin{abstract}
Brazilein performs anti-cancer activities on several cancer cells and potentially inhibits metastasis. The aims of this study is to observe the synergistic cytotoxic and migration inhibitory effect of brazilein combined with cisplatin on 4T1 breast cancer cells. Under MTT assay, we found that brazilein revealed cytotoxic effect on $4 \mathrm{~T} 1$ cells in a dose-dependent manner $\left(\mathrm{IC}_{50}=50 \pm 0.3 \mu \mathrm{M}\right)$. Combination of brazilein and cisplatin showed synergistic effect $(\mathrm{CI}=0.72)$. Flowcytometry analysis on the cell cycle progression showed that single treatment of $25 \mu \mathrm{M}$ brazilein induced G2/M-phase accumulation, $12.5 \mu \mathrm{M}$ cisplatin induced S-phase accumulation, while combination of brazilein and cisplatin induced S-phase and G2/Mphase accumulation. Combination of brazilein and cisplatin induced apoptosis higher than that of the single treatments. Based on wound healing assay, $12.5 \mu \mathrm{M}$ brazilein and its combination with $6.25 \mu \mathrm{M}$ cisplatin inhibited cells migration. Immunoblotting and gelatin zymography analysis showed that combination of brazilein and cisplatin inhibited the expression level of Rac1 and MMP9 proteins. Based on these results, we conclude that brazilein enhanced cytotoxic activity of cisplatin and inhibited migration on $4 \mathrm{~T} 1$ cells and potentially can be developed as an enhancing cytotoxic and antimetastasis agent.
\end{abstract}

Keywords: Brazilein, cisplatin, combination treatment, cytotoxic effect, cells migration.

\section{Introduction}

Brazilein (Figure 1), a major compound of Caesalpinia sappan L., performs potential antiproliferative effect on several cancer cells. In vitro studies have proven that brazilein exhibit cytotoxic activities and apoptosis induction on MCF-7, T47D, and other breast cancer cell lines (Tao et al., 2011, 2013). These cytotoxic activities are mediated through aberration of some signal transduction, mainly on MAP Kinases signaling pathways (Hsieh et al., 2013). In many cancer cells, MAPKs involve on cancer cell growth and metastasis (Hanahan and Weinberg, 2011). Therefore, the physiologically-targeted

\section{${ }^{*}$ Corresponding author:}

Riris Istighfari Jenie

Faculty of Pharmacy, Universitas Gadjah Mada, Indonesia, 55281

E-mail: riris_jenie@ugm.ac.id mechanism of brazilein as anti-cancer on some specific cancer cells need to be explored.

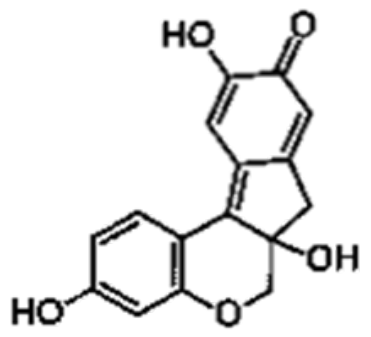

Figure 1. Chemical structure of brazilein (Laksmiani et al., 2015)

Strategy on cancer treatment is not only focused on one target mechanism, but it should be developed on several target mechanism. On the other hand, cancer progression usually involve aberration of cell proliferation and cell migration as well as invasion (Kemper et al., 2014). The $4 \mathrm{~T} 1$ cell is the example of metastatic breast cancer that 
performs active proliferation, migration and invasion (Kaur et al., 2012). Some growth signaling involve in the 4T1 cells proliferation including activation of NF-KB transcription factor (Tsubaki et al., 2013). Our previous research performs that brazilein inhibits proliferation on MCF-7 breast cancer cells via inhibition of NF-kB activation (unpublished data). Hsieh et al., (2013) reported that brazilein inhibits NF- $\mathrm{kB}$ activation leading to inhibition of migration on MDAMB-231 cells. Since NF-kB activation usually increase the side effect of chemotherapeutic agent such as cisplatin and doxorubicin, therefore the exploration of reduction of side effect through NF-KB signaling is needed to be explored. Our previous study showed that brazilein inhibits doxorubicin resistant-MCF-7 cancer cells growth (Laksmiani et al., 2015). In this regards, Brazilein has a potential effect to be developed as co-chemotherapeutic agent against cisplatin as well as doxorubicin.

Cell migration and invasion are indispensable of the metastasis process. Tumor metastasis is a complex process that allows the tumor cells grow on a variety of other tissues and organs. Metastasis occur when tumor cells shed from a primary tumor cells by damaging the extracellular tissues, migrate, invade surrounding tissue, enter the bloodstream and reach the target of a certain tissue to form secondary tumors (Brooks et al., 2010). Cisplatin (CDDP) is one of the first line therapy in metastatic triple negative breast cancer (Zhang et al., 2015). Surprisingly, low concentration of cisplatin induces epithelial-to-mesenchymal transition (EMT) and followed by increasing instead of inhibiting of cancer metastasis (Latifi et al., 2011). On the other hand, brazilein suppresses cancer cells migration and invasion on MDAMB-231 cells (Hsieh et al., 2013). It is interesting to know whether brazilein performs a potential effect to inhibit cisplatin induced-migration and invasion on 4T1 cells.

NF-kB plays a role on cell proliferation and metastasis through the activation of targeted gene expression such as MMP9 and MMP2 (Hsieh et al., 2013; Kim, 2010). The 4T1 cells also performs such of this phenomenon
(Amin et al., 2015). Matrix metalloproteinases (MMPs) belong to a family of zinc-dependent endopeptidases, highly conserved and structurally related, capable of degrading many components of basement membrane and extracellular matrix (ECM). The active MMPs bind with membrane molecules and degrade ECM (Hua et al., 2011). Brazilein inhibits MMP2 protein in both its expression and activation on MDAMB-231 cells (Hsieh et al., 2013). On the other hand, cisplatin induces migration mediated by inducing of Rac1 protein expression (Geng et al., 2016). The Rac1 protein is a member of RHO family of small GTPase that plays a role in neoplastic transformation, tumor progression and metastasis. Activation of p120/Vav2 and PI3K pathways activate Rac1 protein leading to lamellipodia formation through ASP-family verprolin-homologous proteins (WAVEs) and p21-activated kinases (PAK1) activation (Ridley, 2015; Valls et al., 2012). Our main purpose of this study is to explore the cytotoxic and antimetastasis potential of brazilein focusing on inhibiting of migration through inhibition of Rac1 and MMP9 protein expression on 4T1 cells.

\section{Materials and Methods}

\section{Samples}

Brazilein (Be) isolated from Caesalpinia sappan L. was obtained from Cancer Chemoprevention Research Center (CCRC), Faculty of Pharmacy, Universitas Gadjah Mada. Cisplatin (CDDP) was purchased from Sigma (P-4394).

\section{Cell culture}

4T1 metastatic cell line (ATCC CRL2539) was kindly given by Prof. Dr. Mashashi Kawaichi (NAIST) and was cultured in Dulbecco's Modified Eagle Medium (DMEM) medium (Gibco) with 10\% Fetal Bovine Serum (Gibco), 1.5\% Penicillin-Streptomycin (Gibco) and $0.5 \%$ fungizone (Gibco).

\section{Cytotoxic assay}

4T1 cells in 96-well plates with $10^{4}$ cells/well were treated with various concentration of treatment groups. After 24 
$\mathrm{h}$ incubation, culture medium was removed and cells were washed in PBS (Sigma). Then, cells were incubated with $100 \mu \mathrm{L}$ culture medium and $10 \mu \mathrm{L}$ MTT (Sigma) $5 \mathrm{mg} / \mathrm{mL}$ in every well for $4 \mathrm{~h}$. MTT reaction was stopped by SDS reagent (10\% Sodium dodecyl sulphate (Merck) in $0.01 \mathrm{M} \mathrm{HCl}$ (Merck)) and was incubated overnight. The absorbance was measured by ELISA reader (Bio-Rad) at wave length of $595 \mathrm{~nm}$.

\section{Cell cycle assay}

Propidium iodide (PI) staining kit (Becton Dickinson) was used to analyze DNA content. Cells were seeded in 24-well plates with $5 \times 10^{4}$ within $24-48 \mathrm{~h}$. Cells were treated with various concentration of samples in single and combination. After a $24 \mathrm{~h}$ treatment, cells were harvested, and the cells were resuspended in PBS, fixed with $70 \%$ ethanol, labeled with PI $(2 \mu \mathrm{g} / \mathrm{mL})$, and incubated at room temperature in the dark for $10 \mathrm{~min}$. DNA content was analyzed using a flow cytometry (Becton Dickinson) and followed by flowing software (version 2.5.1).

\section{Apoptosis assay}

Apoptotic population was determined by PI-Annexin V assay (Annexin V-FITC Apoptosis Detection Kit Roche). Cells were seeded in 24-well plates with $5 \times 10^{4}$ within 24-48 h. Cells were treated with various concentration of samples in single and combination. After a $24 \mathrm{~h}$ treatment, cells were harvested, added with $1 x$ binding buffer, labeled with PI-Annexin V, and incubated at room temperature in the dark for $5 \mathrm{~min}$. Then the cells suspension was analyzed using a flow cytometry (Becton Dickinson).

\section{Wound healing assay}

Cells were seeded in each well of 24well plate with $1 \times 10^{5}$ cells and incubated at $37^{\circ} \mathrm{C}$ in $\mathrm{CO}_{2}$ incubator for $24 \mathrm{~h}$. Thereafter cell were starved by using serum free-medium (containing $0.5 \%$ fetal bovine serum) for 24 h. The confluent cell monolayers were wounded by a yellow-tip. After washing once with PBS, the cells were added with DMEM culture medium which contained of $1 / 4 \mathrm{IC}_{50}$ of samples in single and combination. Time- lapse images were acquired at 18, 24 and 42 h. Percent of closured were analyzed by using Image-J software.

\section{Gelatin zymography assay}

MMP-9 activity was assayed by gelatin zymography. Cells were seeded in each well of 6-well plate with $1 \times 10^{6}$ cells and incubate at $37^{\circ} \mathrm{C}$ in $\mathrm{CO}_{2}$ incubator for $24 \mathrm{~h}$. Cells were incubated with $1 / 4 \mathrm{IC}_{50}$ of samples in single and combination in serum free-medium for $24 \mathrm{~h}$. The supernatants were collected and subjected to gel electrophoresis on $10 \%$ running gel containing $0.1 \%$ gelatin. The gel were washed in renaturing solution containing $2.5 \%$ Triton $\mathrm{x}-100$ for $30 \mathrm{~min}$, and followed by incubation for $20 \mathrm{~h}$ at $37^{\circ} \mathrm{C}$ with incubation buffer. The gels were stained for $30 \mathrm{~min}$ in $0.5 \%$ coomassie brilliant blue and then destained with destaining solution $(10 \% \mathrm{v} / \mathrm{v}$ methanol and 5\% v/v acetic acid). Gel were scanned and analyzed with image-J software.

\section{Immunoblotting assay}

Cells were seeded in $10 \mathrm{~cm}$ cultured dish with $1 \times 10^{6}$ cells and incubated at $37^{\circ} \mathrm{C}$ in $\mathrm{CO}_{2}$ incubator for $24 \mathrm{~h}$. Cells were incubated with $1 / 4 \quad \mathrm{IC}_{50}$ of samples in single and combination for $24 \mathrm{~h}$. Cell were collected with RIPA buffer (25 mM Tris- $\mathrm{HCl}$ at $\mathrm{pH} 7.6,150$ $\mathrm{mM} \mathrm{NaCl}, 1 \% \mathrm{NP}-40,1 \%$ deoxycholic acid$\mathrm{Na}, 0.1 \%$ SDS, protease and phosphatase inhibitor cocktail). Protein samples were obtained using Bradford method and were measured by microplate reader (SH-1000, Corona electric), separated by electrophoresis on $7-15 \%$ SDS polyacrylamide gel electrophoresis (PAGE) gels, and electrotransferred onto PVDF transfer membranes (Immobilon, millipore). After blocking with $1 \times$ NET gelatin, the membranes were probed with antibodies for Rac1 (33186, Abcam), p120 (sc-13957) and B-actin (sc-47778, Santa Cruz Biotechnologies, Santa Cruz, CA), and then exposed to horseradish peroxidase (HRP)conjugated secondary anti-mouse (sc-2031, Santa Cruz Biotechnologies, Santa Cruz, CA) or anti-rabbit antibodies (7074P2, Cell signaling). Protein expression was examined using the enhanced chemiluminescence (ECL) system (Amersham). 


\section{Statistical analysis}

Parameter of inhibitory concentration $\left(\mathrm{IC}_{50}\right)$ and combinatory index $(\mathrm{CI})$ were measured based on the previous reports (Mosmann, 1983; Reynolds and Maurer, 2005). The $\mathrm{IC}_{50}$ values of three independent experiments were expressed as mean \pm standard deviation (SD). Analysis of significantly between control/untreated group and treated groups were analyzed by unpaired Student's $t$-test (Microsoft Excel 2013). Mean differences was significant at the $P<0.05$.

\section{Results}

\section{Brazilein and cisplatin performed synergistic effect on $4 T 1$ cells}

The confirmation of the cytotoxic activity of brazilein is important to be established as a basic anti-cancer performance and to be developed for the other anti-cancer activities. We used MTT assay as a standard method to measure the cytotoxic activity. After $24 \mathrm{~h}$ treatment, brazilein and cisplatin performed cytotoxic activities in a dosedependent manner with $\mathrm{IC}_{50}$ values of $50 \pm$
$0.3 \mu \mathrm{M}$ and $26 \pm 0.5 \mu \mathrm{M}$, respectively (Fig.2A-B). Furthermore, to confirm whether the compound affects on cytotoxic of cisplatin, we carried out combination treatment with series of concentrations under $\mathrm{IC}_{50}$ value. The synergistic combination was measured by combination index $(\mathrm{CI})$ parameter. The result showed that combination of $1 / 10,1 / 8,1 / 4$, and $1 / 2 \mathrm{IC}_{50}$ of brazilein and cisplatin exhibited synergistic effect on inhibition of $4 \mathrm{~T} 1$ cells growth with CI values less than 1 (Fig. 2C-D). The combination of $1 / 2 \mathrm{IC}_{50}$ of brazilein and cisplatin inhibited cell viability by $62 \%$. These results showed that brazilein possessed cytotoxic activity on $4 \mathrm{~T} 1$ cells with a middle intensity but potential to be developed as cochemotherapeutic agent. Whereas the combination treatment showed that brazilein increased the sensitivity of 4T1 cells upon cisplatin treatment. The cytotoxic activity of brazilein in single and combination with cisplatin may occur due to inhibition of cell cycle modulation or apoptosis induction. Thus, we conducted experiments to observe the cell cycle modulation and apoptosis event

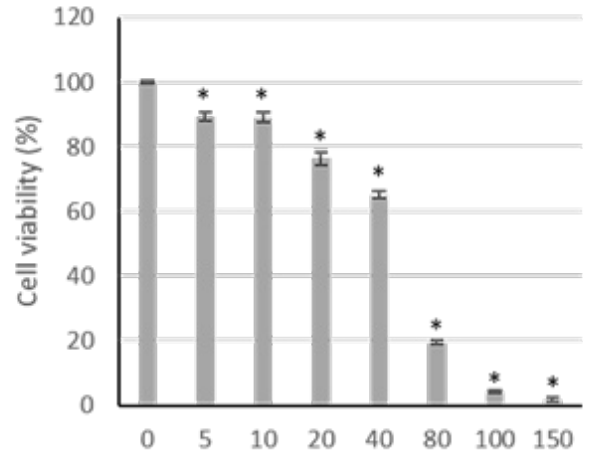

A

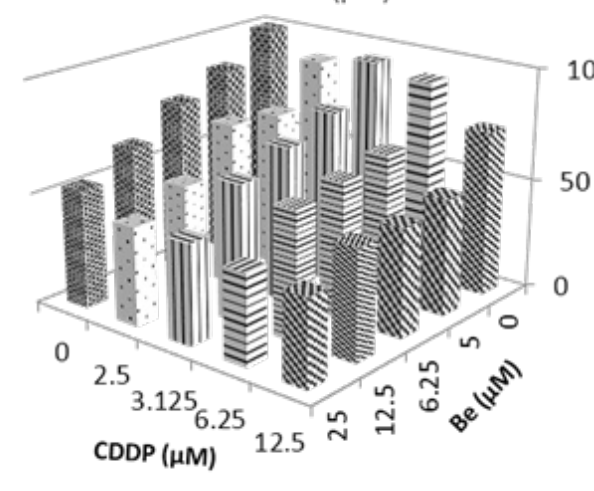

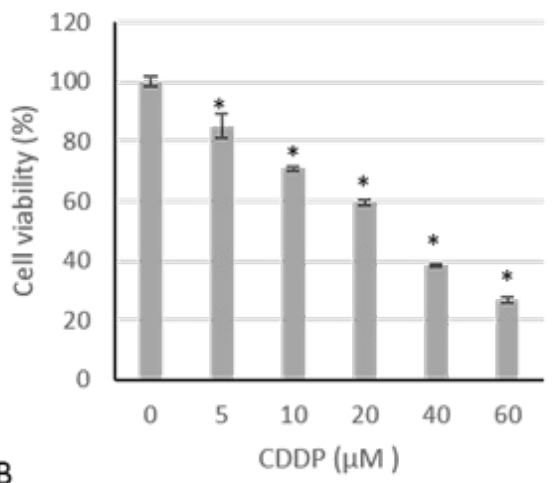

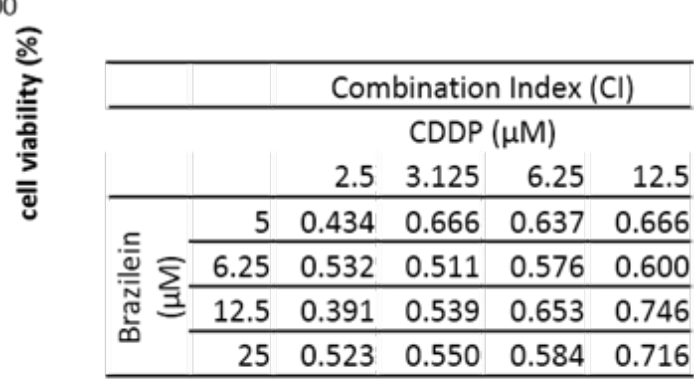

Figure 2. Cytotoxic effect of single treatment of brazilein and its combination with cisplatin on $4 \mathrm{~T} 1$ cells. Cells were treated with various concentration of samples as indicated in the figure for $24 \mathrm{~h}$ and subjected for MTT assay. A. Brazilein $(1-150 \mu \mathrm{M})$, B. Cisplatin $(5-60 \mu \mathrm{M})$, C. Combination of brazilein-cisplatin $\left(1 / 10-1 / 2\right.$ IC $\left._{50}\right)$, D. The CI value of combination of brazilein-cisplatin. Error bar means standard deviation ( $n=3$; * $P<0.05$, Student's $t$-test). 
upon treatment with brazilein and cisplatin.

Combination of brazilein and cisplatin induced cell cycle arrest on $4 T 1$ cells.

To observe the specific mechanism of brazilein and its combination with cisplatin on inhibition of cell cycle progression, we analyze the cell cycle profiles after treatment of samples for $24 \mathrm{~h}$ by using flow cytometry. The results indicated that single treatment of $1 / 2 \mathrm{IC}_{50}$ of brazilein caused sub-G1 and G2/M-phase accumulation (Fig. 3B, 3E), while cisplatin caused S-phase accumulation (Fig. 2C, 2E) compared to untreated cells (Fig. 3A, $3 \mathrm{E})$. The combination of brazilein and cisplatin $\left(1 / 2 \quad \mathrm{IC}_{50}\right)$ increased the cells accumulation in S-phase and G2/M-phase (Fig. 3D-E). Furthermore, these data showed that the cytotoxic activity of brazilein in single and in combination with cisplatin induced sub-G1. These phenomena suggested that the treatment of brazilein in single and in combination with cisplatin may induce cell death.

\section{Combination of brazilein and cisplatin} induced apoptosis on $4 T 1$ cells.

Next, we observed the effect of brazilein in single and in combination with cisplatin on apoptosis induction. Apoptosis is a programmed physiological event leading to cell death that involving the changing of membrane dynamic, nuclear fragmentation and usually become necrosis at the end (Ouyang et al., 2012). Therefore, to examine the phenomenon of brazilein and its combination with cisplatin on apoptosis inc.ıction we performed PI-anexin V staining by using flow cytometry. The result showed that single treatment of $25 \mu \mathrm{M}$ brazilein and $12.5 \mu \mathrm{M}$ cisplatin exhibited total apoptosis (early and late apoptosis) up to $19 \%$ and $13 \%$ respectively (Fig. 4B,4C,4), while combination of brazilein and cisplatin exhibited total apoptosis up to $30 \%$ (Fig. 4D-E) and increase the necrotic cells. These data suggested that combination of brazilein and cisplatin increased cells death compared to the single treatments on $4 \mathrm{~T} 1$ cells.

There are internal and external molecular event in metastasis processes.
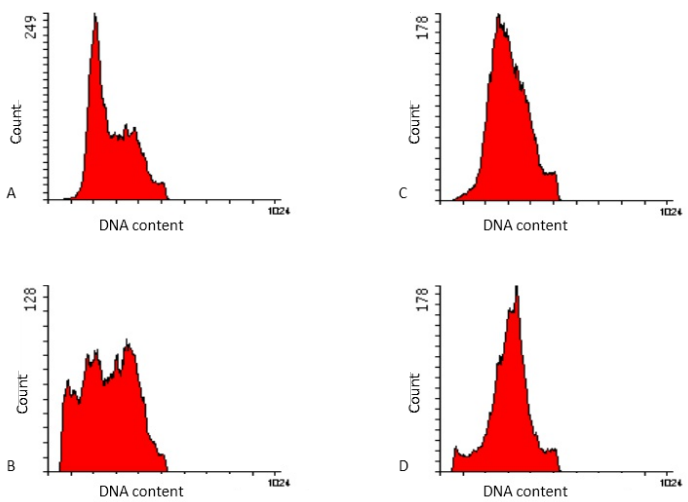

\begin{tabular}{lcccc}
\hline & Untreated & CDDP & Be & Be-CDDP \\
\hline Sub-G1 & 0.44 & 0.97 & 14.21 & 4.55 \\
\hline G0/G1 & 49.25 & 28.73 & 33.46 & 19.35 \\
\hline S & 21.65 & 38.5 & 22.3 & 42.52 \\
\hline G2/M & 28.56 & 31.84 & 30.19 & 33.45 \\
\hline
\end{tabular}

Figure 3. The effect of single treatment of brazilein and its combination with cisplatin on cell cycle profiles on 4T1 cells. Cells were treated with vehicle (A), $25 \mu \mathrm{M}$ brazilein (B), $12.5 \mu \mathrm{M}$ cisplatin (C), and combination of brazilein-cisplatin (D) for $24 \mathrm{~h}$, stained with PI and analyzed by using flow cytometry according to the method and quantified by using flowing software (E).
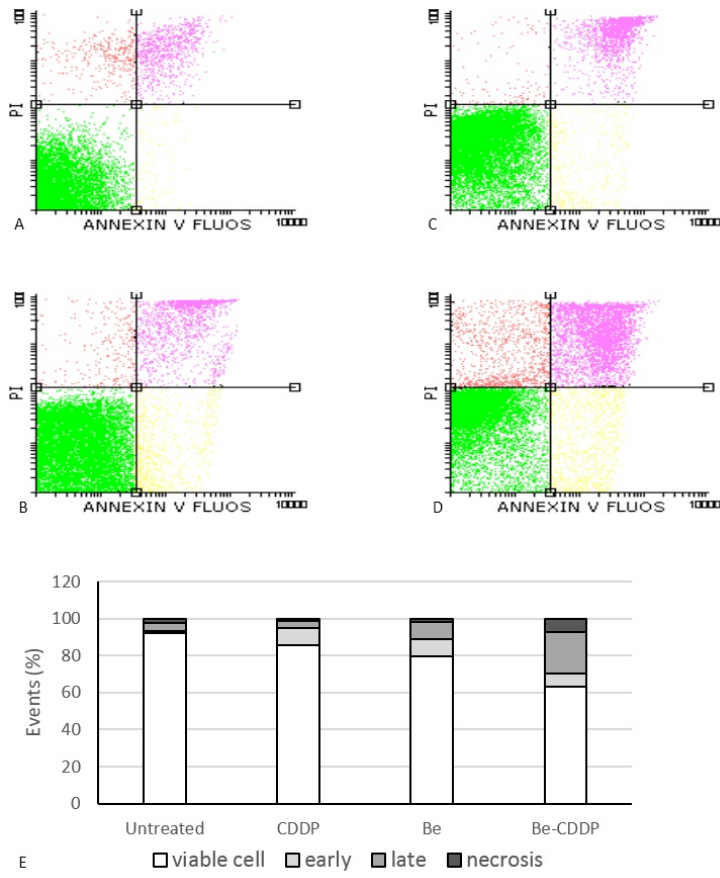

Figure 4. The effect of single treatment of brazilein and its combination with cisplatin on apoptosis induction on 4T1 cells. Cells were treated with vehicle (A), $25 \mu \mathrm{M}$ brazilein (B), $12.5 \mu \mathrm{M}$ cisplatin (C), and combination of brazilein-cisplatin (D) for $24 \mathrm{~h}$, stained with PI-Annexin $\mathrm{V}$ and analyzed by using flow cytometry according to the method and quantified by using flowing software (E).

Internal molecular signaling during migration process involves actin polymerization and lamellipodia formation. This event mainly 


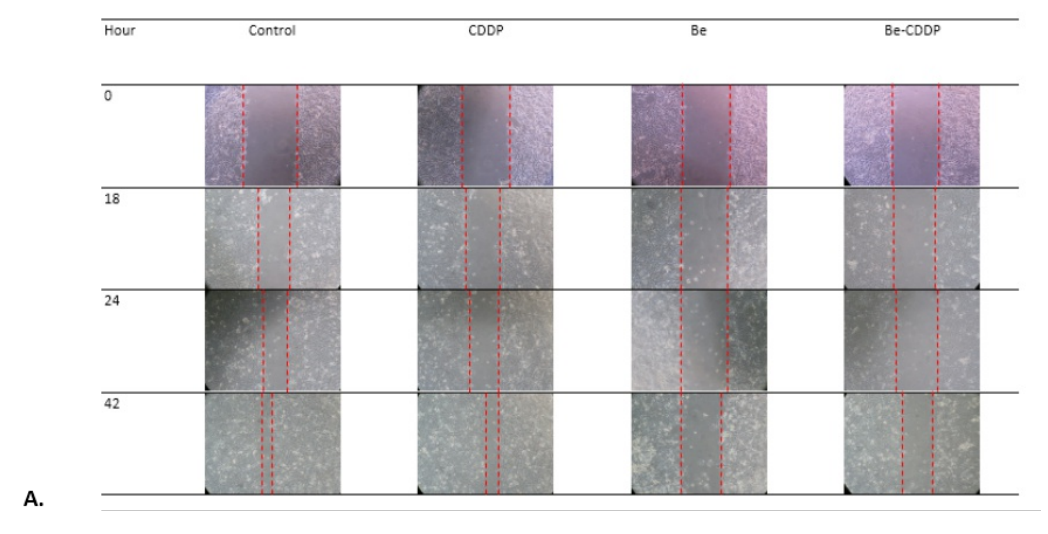

B.

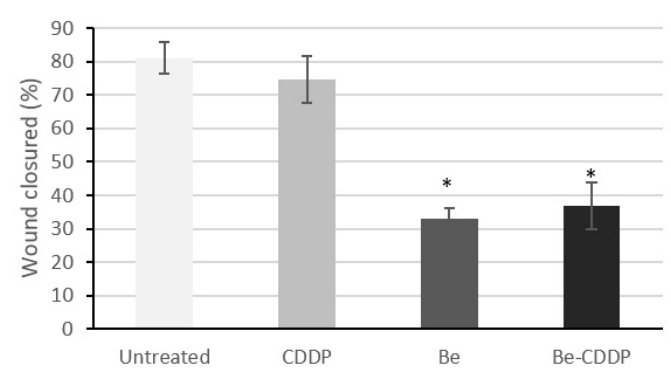

Figure 5. The effect of single treatment of brazilein and its combination with cisplatin on 4T1 cells migration. Cells were scratched according to wound healing assay, were treated with $12.5 \mu \mathrm{M}$ brazilein and $6.25 \mu \mathrm{M}$ cisplatin in single and in combination, were photographed at $0,18,24$, and $42 \mathrm{~h}$, then analyzed by using image J software. A. Wound closured, B. Relative wound closured after $42 \mathrm{~h}$ samples treatment. Error bars mean standard deviation $(n$ $=3,{ }^{*} P<0.05$, Student's $t$-test).

induce by the expression and activation of Rac1 and p120 (Valls et al., 2012). On the other hand, cancer progression is also marked by highly expression of proteinases in the microenvironment such as MMP9 to impair ECM (Hua et al., 2011). Therefore, to confirm whether the mechanism underlying migration inhibition of brazilein, we performed gelatin zymography to analyze the level of MMP9 in the environment and immunoblotting experiment to analyze the level of Rac1 and p120 protein in the cells. The level of MMP9 in the medium of $4 \mathrm{~T} 1$ cells was decreased in response to treatment $12.5 \mu \mathrm{M}$ brazilein and its combination with $6.25 \mu \mathrm{M}$ cisplatin (Fig. 6A-B). Single treatment of $6.25 \mu \mathrm{M}$ cisplatin did not significantly reduce the MMP9 level suggested that the decreasing of MMP9 level in the combination treatment was due to brazilein. Furthermore, brazilein and its combination with cisplatin decreased Rac1 protein expression but not p120 in the 4T1 cells (Fig. 6B).

\section{Discussion}

The 10 hallmarks of cancer noted that cell cycle modulation, apoptosis induction, and inhibition of metastatic stages of cancer become important targets in cancer therapy development (Hanahan and Weinberg, 2011). In this report, we present the effect of brazilein on several physiological targets on cancer development, especially on metastatic breast cancer cells. We used $4 \mathrm{~T} 1$ cells line that has been recognized as active cells in proliferation and migration (Kaur et al., 2012). Comprehensively, we found that brazilein exhibited middle or low cytotoxic effect, cell cycle modulation, apoptosis induction, and inhibition of cells migration. These results supported our previous data and other results reported elsewhere (Hsieh et al., 2013; Laksmiani et al., 2015; Tao et al., 2011, 2013). Our data give additional information concerning on the physiological effects of brazilein in single and in combination with cisplatin on a progressive cell line, $4 \mathrm{~T} 1$.

In this study, we showed that brazilein performed cytotoxic effect to $4 \mathrm{~T} 1$ cells with $\mathrm{IC}_{50}$ value of $50 \pm 0.3 \mu \mathrm{M}$. This cytotoxic value is categorized as low level according to Larsson et al. (2006). Functional food such as Caesalpinia sappan L. commonly safe and less toxic on cells (Nirmal et al., 2015). 
Nevertheless, we should consider when we consume this plant in high consumption because brazilein is the major compound in this plant. However, the synergistic effect with cisplatin in enhancing cytotoxicity on the cells gives insight for the use of brazilein to enhance the chemotherapeutic effect (the efficacy) and to reduce the side effect of cisplatin. Even we still do not know the molecular mechanism underlying this synergistic effect, but at least we have information that lower concentration of cisplatin gave the same cytotoxic effect to the cells when it combined with brazilein. This phenomenon also performed by brazilein in combination with doxorubicin which sensitized MCF-7 resistant doxorubicin cancer cells (Laksmiani et al., 2015), thus, gives good prospect of brazilein to be developed as co chemotherapeutic agent. However, this data

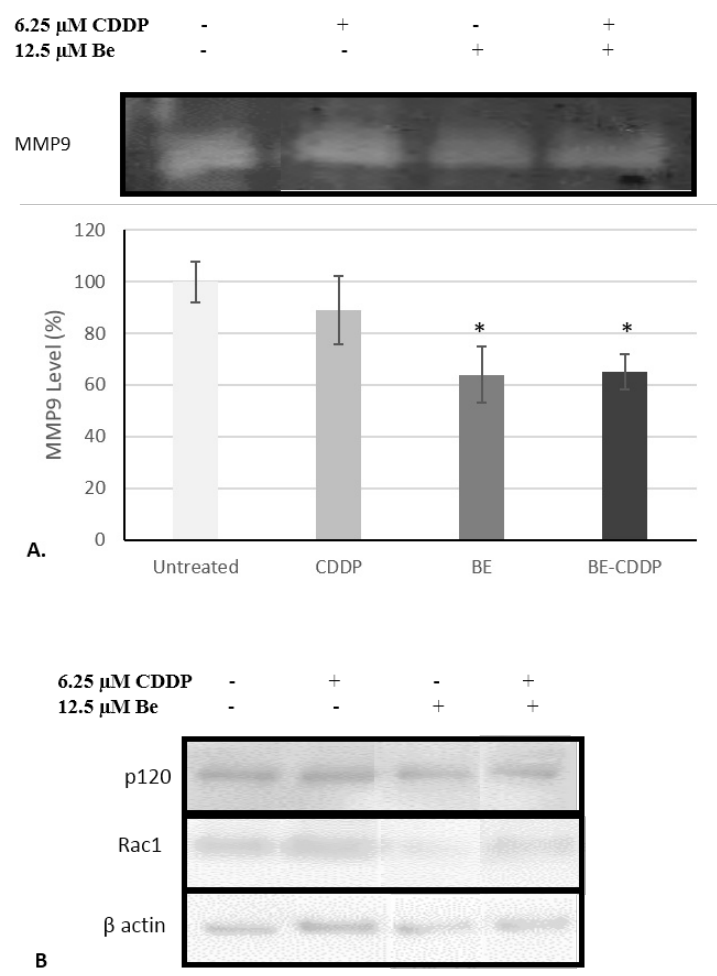

Figure 6. The effect of single treatment of brazilein and its combination with cisplatin in MMP9 and Rac1 protein level in $4 \mathrm{~T} 1$ cells. Cells were treated with $1 / 4$ $\mathrm{IC}_{50}$ of single and combination of brazilein and cisplatin for $24 \mathrm{~h}$ and were observed by gelatin zymography and immunoblotting assay. A. Graphic of MMP9 protein level. B. p120 and Rac1 protein level of samples on 4T1 cells. Analysis of protein level of MMP9 was calculated by using ImageJ software. Error bars mean standard deviation $\left(n=3,{ }^{*} P<0.05\right.$, Student's $t$-test $)$. are the in vitro report and should be confirmed with in vivo experiment.

The shift of cell cycle profile in combination treatment of brazilein-cisplatin is an interesting finding in this study. Based on the cell cycle profiles, brazilein showed different mechanism compare to cisplatin. Cisplatin is well known to induce cell cycle arrest at S-phase (Shen et al., 2013) and our finding showed the same phenomenon. However, brazilein induced cell accumulation in G2/M phase. This phenomenon is similar with the effect of brazilin (the reduced form of brazilein) that induces cell accumulation in G2/M phase on myeloma U266 cells (Kim et al., 2012). Moreover, the different shifting of cell cycle profiles between cisplatin and brazilein indicated the differences targets of the two compounds, especially on the cell cycle regulation that should be investigated further. The differences of the targets mechanism are important to potentiate the cytotoxic effect to the cancer cells (Chou, 2006). In this regards, we confirmed that the combinational treatment of both compounds gave synergistic effect to inhibit cells growth by $>50 \%$ (Fig. 2C-D). Our data also showed that brazilein pulled the cells into sub-G1 phase indicated that this compound induces cell death or apoptosis. However, the combination treatment seemed to reduce the cell death (decrease the sub-G1 phase by $4 \%$ ). This decreasing of the sub-G1 accumulation may be due to most of the apoptotic cells underwent necrosis. This phenomenon was confirmed by PI-annexin V staining under flocytometry assay (Fig. 4D-E). Apoptosis leading to necrosis is the normal phenomenon in in vitro studies of cell death due to the absent of the phagocytic cells (Ouyang et al., 2012). Our result suggested that the combination treatment of brazilein and cisplatin enhanced cell cycle arrest and accelerated the apoptosis evidence.

Brazilein was reported to inhibit migration and invasion in MDAMB-231 breast cancer cells (Hsieh et al., 2013). Metastasis is a fatal state of cancer progression, which needs migration and 
invasion to initiate the process. Targeted therapy to inhibit those two processes would be beneficially for triple negative cancer cells treatment that have characteristic of highly metastasis (Ferrari-Amorotti et al., 2014; Martin et al., 2013). The present data showed that brazilein, in single and in combination with cisplatin inhibited cells migration (Fig. 5) of 4T1 cells. Furthermore, we observed that single treatment of brazilein and its combination with cisplatin suppressed Rac1 protein expression (Fig. 6B). Rac1 is a member of Rho-GTPase family which plays an important role in lamellipodium extension together with cdc-42 and Rho-A (Ridley, 2015). Previously, Chen et al., (2014) reported that curcumin inhibits activation of PAK1, the downstream of Rac1, mediated by suppression of Rac1 protein expression. Flavonoid wogonin inhibits Rac1 expression as well as other Ras and activated ERK and PI3K/Akt pathway (Zhao et al., 2014). Upregulation of Rac1 activity is mediated through several signaling pathways including Wnt stimulation that involving binding of p120-catenin with Rac1 and Vav2 (Valls et al., 2012). However, our finding (Fig. 6B) did not show any significance difference of p120-catenin expression among treated and untreated cells. This phenomenon indicated that the cells migration inhibitory effect of brazilein was due to other Rac1 activation mechanism such as PI3K kinase pathway. Kim et al. (2014) reported that rhapontigenin and the PI3K inhibitor wortmannin reduces Rac1 activation in MDAMB-231 cells through inhibition of PI3K-dependent Rac1 signaling pathway.

The MMPs family is important in the invasion step of metastasis to degrade the extra cellular matrix, and among them, MMP9 and MMP2 are known to be highly expressed in metastatic breast cancer cells (Hua et al., 2011). Our study demonstrated that brazilein and its combination with cisplatin decreased the gelatinolytic activity of MMP9 protein in 4T1 cells (Fig 5A-B). It was reported by Hsieh et al. (2013) that brazilein inhibits nuclear translocation of NF-kB protein, thus, suppressing the NF-KB signaling pathway.
NF- $\mathrm{kB}$ is constitutively active in most tumor cell lines and in tumor tissues derived from patients with various types of cancer including breast cancer NF- $\mathrm{kB}$ is resides in the cytoplasm of all cells, however when NF$\mathrm{KB}$ is being activated it will be translocated in the nucleus and affected the downstream gene expression. MMP9 is one of many gene products regulated by NF- $\mathrm{KB}$ activation (Aggarwal, 2004). Taken together, our findings indicated that brazilein and that suppression of NF-kB signaling may be involved in the mechanism. However, further studies are needed to clarify the molecular mechanism underlies brazilein and its combination in modulating cell cycle, inducing apoptosis and inhibiting migration and invasion in metastatic breast cancer cells.

\section{Conclusions}

This study concludes that brazilein worked synergistically with cisplatin to inhibit proliferation and migration in 4T1 cancer cells through inhibition of MMP9 and Rac1 protein expression.

\section{Acknowledgments}

This work was supported by the grant of Penelitian Unggulan Perguruan Tinggi (PUPT) 2015-2016 from Indonesian Ministry of Research, Technology and High Education.

\section{References}

Aggarwal, B.B. 2004. Nuclear factor-kappaB: the enemy within. Cancer Cell, 6, 203-208. doi:10.1016/j.ccr.2004.09.003.

Amin, H., Wani, N.A., Farooq, S., Nayak, D., Chakraborty, S., Shankar, S., Rasool, R. ur, Koul, S., Goswami, A., Rai, R. 2015. Inhibition of Invasion in Pancreatic Cancer Cells by Conjugate of EPA with $\beta 3$,3-Pip-OH via PI3K/Akt/NFkB Pathway. ACS Med. Chem. Lett., 6, 1071-1074. https://doi:10.1021/ acsmedchemlett.5b00257.

Baribeau, S., Chaudhry, P., Parent, S., Asselin, É. 2014. Resveratrol Inhibits CisplatinInduced Epithelial-to-Mesenchymal Transition in Ovarian Cancer Cell Lines. PLOS ONE, 9, e86987. https:/ / doi:10.1371/journal.pone.0086987. 
Brooks, S.A., Lomax-Browne, H.J., Carter, T.M., Kinch, C.E., Hall, D.M.S. 2010. Molecular interactions in cancer cell metastasis. Acta Histochem., 112, 3-25. https://doi:10.1016/j.acthis.2008.11.02 2.

Chen, Q., Zheng, Y., Jiao, D., Chen, F., Hu, H., Wu, Y., Song, J., Yan, J., Wu, L., Lv, G. 2014. Curcumin inhibits lung cancer cell migration and invasion through Rac1-dependent signaling pathway. J. Nutr. Biochem., 25, 177-185. https:/ / doi:10.1016/j.jnutbio.2013.10.004.

Chou, T.-C. 2006. Theoretical Basis, Experimental Design, and Computerized Simulation of Synergism and Antagonism in Drug Combination Studies. Pharmacol. Rev., 58, 621-681. https:/ / doi:10.1124/pr.58.3.10.

Ferrari-Amorotti, G., Chiodoni, C., Shen, F., Cattelani, S., Soliera, A.R., Manzotti, G., Grisendi, G., Dominici, M., Rivasi, F., Colombo, M.P., Fatatis, A., Calabretta, B. 2014. Suppression of Invasion and Metastasis of TripleNegative Breast Cancer Lines by Pharmacological or Genetic Inhibition of Slug Activity. Neoplasia, 16, 1047-1058. https://doi:10.1016/ j.neo.2014.10.006.

Geng, S., Gu, L., Ju, F., Zhang, H., Wang, Y., Tang, H., Bi, Z., Yang, C. 2016. MicroRNA-224 promotes the sensitivity of osteosarcoma cells to cisplatin by targeting Rac1. J. Cell. Mol. Med., 20, 1611-1619. https:// doi:10.1111/jcmm.12852.

Hanahan, D., Weinberg, R.A. 2011. Hallmarks of Cancer: The Next Generation. Cell 144, 646-674. https://doi:10.1016/ j.cell.2011.02.013

Hsieh, C.-Y., Tsai, P.-C., Chu, C.-L., Chang, F.-R., Chang, L.-S., Wu, Y.-C., Lin, S.R. 2013. Brazilein suppresses migration and invasion of MDA-MB-231 breast cancer cells. Chem. Biol. Interact., 204, 105-115. https://doi:10.1016/ j.cbi.2013.05.005.

Hua, H., Li, M., Luo, T., Yin, Y., Jiang, Y. 2011. Matrix metalloproteinases in tumorigenesis: an evolving paradigm. Cell. Mol. Life Sci., 68, 3853-3868. doi:10.1007/s00018-011-0763-x.

Kaur, P., Nagaraja, G.M., Zheng, H., Gizachew, D., Galukande, M., Krishnan, S., Asea, A. 2012. A mouse model for triple-negative breast cancer tumor-initiating cells (TNBC-TICs) exhibits similar aggressive phenotype to the human disease. BMC Cancer, 12, 120. https:/ / doi:10.1186/1471-2407-12120.

Kemper, K., Goeje, P.L. de, Peeper, D.S., Amerongen, R. van. 2014. Phenotype Switching: Tumor Cell Plasticity as a Resistance Mechanism and Target for Therapy. Cancer Res., 74, 5937-5941. https://doi:10.1158/0008-5472.CAN14-1174.

Kim, B.S. 2010. Brazilin Inhibits of TPAinduced MMP-9 Expression Via the Suppression of NF-kB Activation in MCF-7 Human Breast Carcinoma Cells. J. Food Hyg. Saf.

Kim, J.S., Kang, C.G., Kim, S.-H., Lee, E.-O. 2014. Rhapontigenin Suppresses Cell Migration and Invasion by Inhibiting the PI3K-Dependent Rac1 Signaling Pathway in MDA-MB-231 Human Breast Cancer Cells. J. Nat. Prod., 77, 1135-1139. doi:10.1021/np401078g.

Laksmiani, N.P.L., Susidarti, R.A., Meiyanto, E. 2015. Brazilein Increases The Sensitivity of Doxorubicin on MCF-7 Resistant Doxorubicin (MCF-7/DOX) Cells Through Inhibition of HER-2 Activation. Int. J. Pharm. Pharm. Sci., 7, 525-528.

Larsson, D.E., Lövborg, H., Rickardson, L., Larsson, R., Oberg, K., Granberg, D. 2006. Identification and evaluation of potential anti-cancer drugs on human neuroendocrine tumor cell lines. Anticancer Res., 26, 4125-4129.

Latifi, A., Abubaker, K., Castrechini, N., Ward, A.C., Liongue, C., Dobill, F., Kumar, J., Thompson, E.W., Quinn, M.A., Findlay, J.K., Ahmed, N. 2011. Cisplatin treatment of primary and metastatic epithelial ovarian 
carcinomas generates residual cells with mesenchymal stem cell-like profile. J. Cell. Biochem., 112, 2850-2864. doi:10.1002/jcb.23199.

Martin, T.A., Ye, L., Sanders, A.J., Lane, J., Jiang, W.G. 2013. Cancer Invasion and Metastasis: Molecular and Cellular Perspective. Landes Bioscience.

Mosmann, T. 1983. Rapid colorimetric assay for cellular growth and survival: application to proliferation and cytotoxicity assays. J. Immunol. Methods, 65, 55-63.

Nirmal, N.P., Rajput, M.S., Prasad, R.G.S.V., Ahmad, M. 2015. Brazilin from Caesalpinia sappan heartwood and its pharmacological activities: A review. Asian Pac. J. Trop. Med., 8, 421-430. doi:10.1016/j.apjtm.2015.05.014.

Ouyang, L., Shi, Z., Zhao, S., Wang, F.-T., Zhou, T.-T., Liu, B., Bao, J.-K. 2012. Programmed cell death pathways in cancer: a review of apoptosis, autophagy and programmed necrosis. Cell Prolif., 45, 487-498. https:// doi:10.1111/j.1365-2184.2012.00845.x.

Reynolds, C.P., Maurer, B.J. 2005. Evaluating response to antineoplastic drug combinations in tissue culture models. Methods Mol. Med., 110, 173-183. https:// doi:10.1385/1-59259-869-2:173.

Ridley, A.J. 2015. Rho GTPase signalling in cell migration. Curr. Opin. Cell Biol., 36, 103-112. https://doi:10.1016/ j.ceb.2015.08.005.

Shen, H., Perez, R.E., Davaadelger, B., Maki, C.G. 2013. Two 4N Cell-Cycle Arrests Contribute to Cisplatin-Resistance. PLoS ONE, 8, e59848. doi:10.1371/journal.pone.0059848.

Tao, L., Li, J., Zhang, J. 2013. Brazilein, a compound isolated from Caesalpinia sappan Linn., induced growth inhibition in breast cancer cells via involvement of GSK-3 $\beta / \beta$-Catenin/cyclin D1 pathway. Chem. Biol. Interact., 206, 1-5. https://doi:10.1016/j.cbi.2013.07.015.

Tao, L., Li, J., Zhang, J. 2011. Brazilein Induced Cells Apoptosis in Human Breast Cancer MCF-7 Cells and Its Action
Mechanism. J. Sun Yat-Sen Univ. Med. Sci., 32, 449-453.

Tsubaki, M., Komai, M., Fujimoto, S., Itoh, T., Imano, M., Sakamoto, K., Shimaoka, H., Takeda, T., Ogawa, N., Mashimo, K., Fujiwara, D., Mukai, J., Sakaguchi, K., Satou, T., Nishida, S. 2013. Activation of NF-kB by the RANKL/RANK system up-regulates snail and twist expressions and induces epithelial-to-mesenchymal transition in mammary tumor cell lines. J. Exp. Clin. Cancer Res., CR 32, 62. https://doi:10.1186/1756-9966-32-62.

Valls, G., Codina, M., Miller, R.K., Valle-Pérez, B.D., Vinyoles, M., Caelles, C., McCrea, P.D., Herreros, A.G. de, Duñach, M. 2012. Upon Wnt stimulation, Rac1 activation requires Rac1 and Vav2 binding to p120-catenin. J. Cell Sci., 125, 5288-5301. doi:10.1242/jcs.101030.

Zhang, J., Wang, Z., Hu, X., Wang, B., Wang, L., Yang, W., Liu, Y., Liu, G., Di, G., Hu, Z., Wu, J., Shao, Z. 2015. Cisplatin and gemcitabine as the first line therapy in metastatic triple negative breast cancer. Int. J. Cancer, 136, 204-211. https://doi:10.1002/ijc.28966.

Zhao, K., Wei, L., Hui, H., Dai, Q., You, QD., Guo, Q-L., Lu, N. 2014. Wogonin Suppresses Melanoma Cell B16-F10 Invasion and Migration by Inhibiting Ras-Medicated Pathways. PLoS ONE, 9(9): e106458. https:// doi.org/10.1371/ journal.pone.0106458. 